\title{
The potential of forest-derived bioenergy to contribute to China's future energy and transportation fuel requirements
}

\author{
by Ling Li ${ }^{1,2}$, Sergios Karatzos ${ }^{1}$ and Jack Saddler ${ }^{1}$
}

\begin{abstract}
Increasing concerns of oil security, greenhouse gas emissions, and sustainability have encouraged nations to consider the contribution that agriculture/forestry for bioenergy (and biofuels in particular) could make as alternatives to current fossil-based energy and transportation fuels. Despite China's large population and geographical size, it has only relatively recently developed into a highly industrialized and energy-dependent economy. Coal is, and will remain, China's dominant energy source. However, over the last few years with China's growing middle class, increasing growth in production and sale of cars/trucks and a growing chemical based sector, oil and its derivatives are predicted to experience the fastest fossil fuel growth. China's ability to produce so-called "first-generation" or conventional biofuels from sugar, starch or vegetable oil based plants is very restricted because of "food vs. fuel" issues. Thus, biomass-based and forest-based biofuels, in particular, can form a medium-to-long-term solution that could contribute to China's national biofuels targets. Oilseed trees have been suggested as an initial forest-based biodiesel strategy with about 13 million ha of marginal land identified for possible plantation. It is also estimated that 17 million tonnes of cellulosic ethanol per annum could be derived from forest biomass that is currently available in China.
\end{abstract}

Key words: bioenergy, biofuels, transportation fuel, China

\section{RÉSUMÉ}

Les inquiétudes croissantes reliées à l’approvisionnement en pétrole, aux émissions de gaz à effet de serre et à la durabilité ont encouragé les nations à étudier la contribution que pourrait apporter lagriculture/foresterie à des fins de bioénergie (et en particulier de biocarburants) en tant qu’alternative à lénergie tirée actuellement de sources fossiles et aux carburants utilisés pour le transport. Malgré la très forte population de la Chine et sa taille géographique, ce nest que depuis peu qu'elle est devenue une économie fortement industrialisée et grandement dépendante des ressources énergétiques. Le charbon est, et demeurera, la principale source énergétique de la Chine. Cependant, au cours des dernières années à la suite de la croissance de la classe moyenne chinoise, de la croissante accélérée de la production et des ventes d’automobiles et de camions et d'un secteur chimique en expansion, le pétrole et ses dérivées devraient connaitre la plus forte croissance parmi les carburants d’origine fossile. La capacité de la Chine de produire ce qu’on appelle des biocarburants « de première génération » ou conventionnels à partir du sucre, d’amidon et d’huile végétale extraits de plantes est très limitée à cause des enjeux « nourriture vs carburant ». En conséquence, les carburants tirés de la biomasse et des forêts, en particulier, peuvent devenir une solution à moyen et à long terme qui permettrait à la Chine d’atteindre ses objectifs nationaux de production de biocarburants. Les arbres oléagineux ont été suggérés en tant que stratégie initiale de production de biodiesel à partir de forêts qui pourraient sétendre sur les quelque 13 millions d'hectares de terres marginales identifiées comme pouvant être plantées. On estime également que 17 millions de tonnes déthanol cellulosique par année pourraient être dérivés de la biomasse forestière qui est actuellement disponible en Chine.

Mots clés : bioénergie, biocarburants, carburant pour le transport, Chine

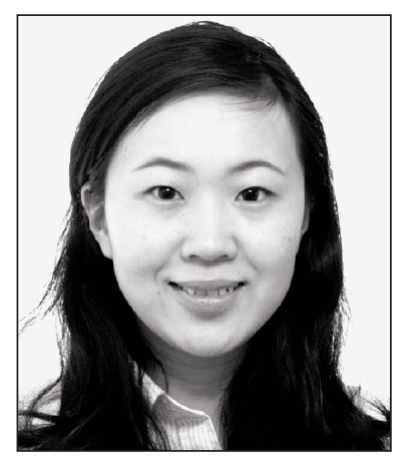

Ling Li

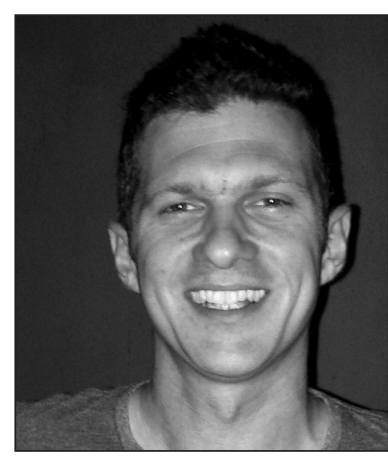

Sergios Karatzos

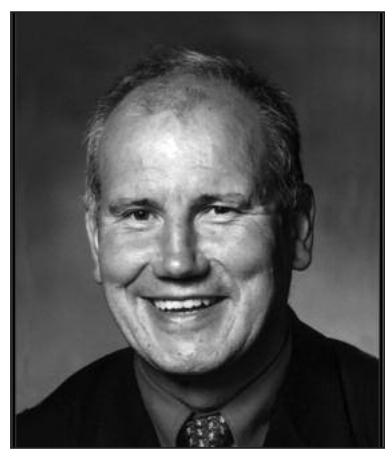

Jack Saddler

\footnotetext{
${ }^{1}$ University of British Columbia, 4041-2424 Main Mall, Vancouver, British Columbia V6T 1Z4.

${ }^{2}$ Author of correspondence. E-mail: lingli0903@gmail.com
} 


\section{Introduction}

The Industrial Revolution is generally viewed as the turning point of a country's energy profile. Historically, in Europe, the US and other OECD countries, industrialization has been associated with growing fossil fuel consumption. Although coal traditionally played the dominant role in the establishment of a country's industrialization, with growing affluence comes the need for oil-derived products such as the fertilizers, plastics, and transportation fuels that most developed countries demand.

China is the world's largest "emerging economy" and it is well into the process of full industrialization as demonstrated by its unprecedented growth in terms of both GDP and energy consumption. Coal has been the obvious choice to feed China's soaring energy demand as it is an abundant fossil fuel in a country that is currently not committed to GHG sequestration targets. Further contributing to China's energy consumption is the continuing move towards a more affluent/energy dependant lifestyle, resulting from higher family incomes (JOY CN 2010). The automobile sector in particular has experienced very rapid domestic market growth due to unprecedented increases in the disposable income of the "middle classes" (NBS 2011b). Consequently, petroleum oil is the fossil fuel that has shown the greatest increase in demand over the last decade-in a country that is already heavily dependent on imported oil (EIA 2011a). As the world's largest coal consumer and the second-largest oil consumer, China needs to strategically diversify its resources to more self-sufficient and renewable forms of energy (BP 2011b).

Forest-based bioenergy and biofuels are sustainable solutions that might initially slow down fossil fuel consumption and ultimately replace some of its current uses. In the work reported here we have reviewed China's energy consumption trends with an emphasis on oil-derived products such as gasoline/diesel while assessing the potential of forest-derived renewable alternatives. These Chinese trends were compared with those of other major energy consuming economies, such as the US and Canada. The role that China's socioeconomic transformation will have on energy consumption is also discussed. Finally, the short- and long-term potential that forestderived bioenergy/biofuels might play in China's future energy and transportation fuel requirements are assessed. However, it is very likely that Chinese government strategies and policies will play a key role in determining how China's forest-based bioenergy and biofuel sectors will be developed.

\section{World's Energy Consumption Trends}

Up until the Industrial Revolution made coal the dominant source of energy and power, the combustion of biomass was the primary source for cooking and heating while horses and oxen provided most of the "horse-power" for farming and other types of heavy labour. Although the Industrial Revolution was the primary reason for the rapid increase in the consumption of coal in much of the $18^{\text {th }}$ century world, it did not fully eclipse wood as the dominant fuel until the early 1900s (Vaughn 2011). After World War II, the rapid development of the internal combustion engine, the related automotive industry and the evolving petrochemical industry all contributed to the rapid increase in oil consumption. Oil has been the world's dominant fuel since 1970 and currently accounts for just over one-third of the total global energy con- sumption (BP 2011b, Vaughn 2011). However, as is discussed in more detail below, this progression and time line was not followed in China. China's economy was operating at almost a pre-industrial revolution scale during the 1950s and 1960s, with little development of the manufacturing or automotive sectors and the related need to shift to more "energy dense" forms of fuel such as oil and coal.

\section{Energy Consumption Trends in China}

Unlike many of the world's economies that followed the progression of coal use during the industrial revolution, followed by the rapid increase in oil and natural gas during and after the Second World War, China has had this "energy evolution" compressed into the last 60 years. Although today China is one of the world's major energy consumers, its per capita energy consumption is lower than the world's average (World Bank 2010a). In 2010, China surpassed the US to become the world's largest energy consumer, accounting for $20 \%$ of total global energy use while the US accounted for 19\% (BP 2011b). When the overall population numbers are taken in to account, Canadian and American energy consumption per capita is, respectively, six and four times higher per capita than that of China (World Bank 2010a). Although China and the US both rely heavily on fossil fuel, oil is the largest energy source for the US, which represents a typical energy profile for a fully industrialized OECD country. In contrast, coal is the largest energy source for China, which is more typical of a non-OECD country that is still in the process of industrialization (Table 1).

The energy consumption trends of China as influenced by the country's industrialization can be divided into three distinct periods over the last six decades (Fig.1.). From the late 1940 s to the late 1970 s, the growth in energy consumption was driven by the development of heavy industry and the production of goods that would help mitigate national security concerns. However, during the late 1970s/early 1980s, Deng Xiaoping initiated refrom policies that opened up the Chinese market to the world. Light industries, such as textile and clothing were the first to benefit from these reform policies and drove the increase in energy consumption for the next 20 years. After China joined the World Trade Organization (WTO) in 2001, the country increased its manufacturing of goods such as electronics and chemicals to essentially become the "world's factory" (Wang 2008). In order to develop the infrastructure required for this massive investment in manufacturing, China reinvested and updated its aging heavy industries to become the world's biggest consumer of raw material commodities such as steel, cement and ferrous metals (Wang 2008). These energy-intensive industries dramatically increased China's energy consumption

Table 1. Comparison of energy consumption by fuel [\%], 2010

\begin{tabular}{lccccc}
\hline Country & Oil & Coal & $\begin{array}{c}\text { Natural } \\
\text { gas }\end{array}$ & $\begin{array}{c}\text { Nuclear } \\
\text { energy }\end{array}$ & $\begin{array}{c}\text { Renewable } \\
\text { energy }\end{array}$ \\
\hline China & 17.6 & 70.5 & 4.0 & 0.7 & 7.2 \\
US & 37.2 & 23.0 & 27.2 & 8.3 & 4.3 \\
\hline
\end{tabular}

Source: BP 2011b 


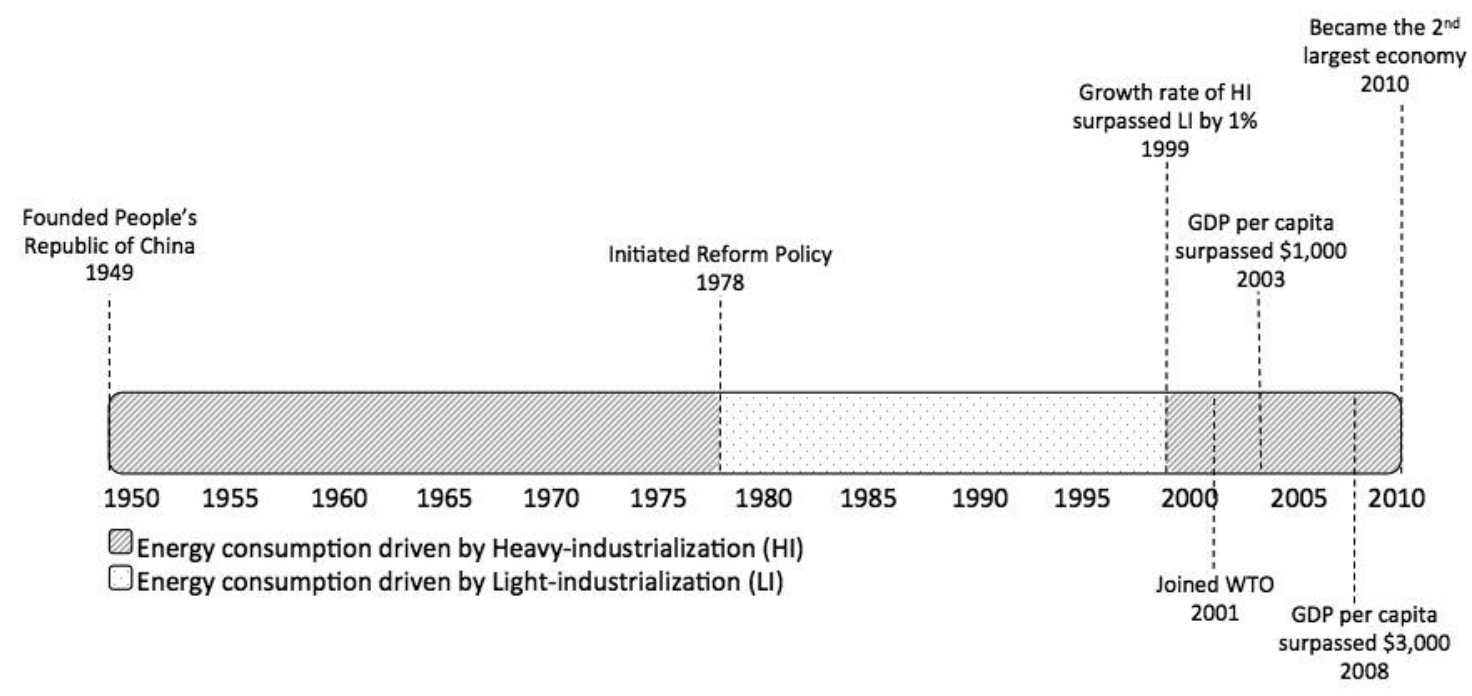

Fig. 1. Timeline of Chinese energy evolution, 1949-2010. Sources: Wang 2008, NBS 2000, 2011a.

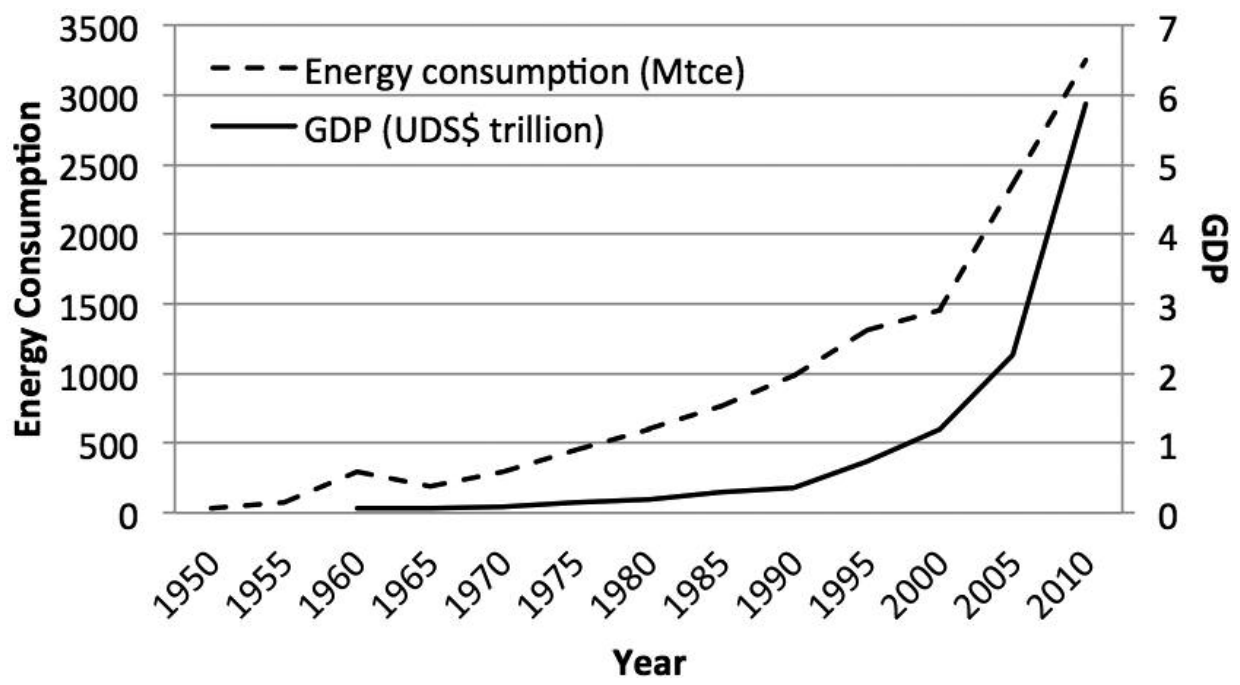

Fig. 2. China's total energy consumption and GDP increased from 1950 to 2010 . Sources: NBS 2011 a, World Bank 2011.

while at the same time, the increase in the disposable income of China's people meant that they could invest in energyconsuming products such as fridges, washing machines, TVs and cars (NBS 2011a).

Thus, the industrialization of China greatly increased its energy consumption and accelerated the nation's GDP growth. These rapid changes in lifestyle and increases in overall consumption of goods almost occurred over one generation, rather than over the multiple generations typically observed in most OECD countries (Fig. 2.). In 2010, China surpassed Japan and became the world's second-largest economy. This recent increase in GDP has significantly improved Chinese people's standards of living. An example of how recent this change in affluence has been is that, between the 1950s and 1970s, most Chinese people would be thrilled to be able to own or acquire "the four big items" which were a sewing machine, a bicycle, a wristwatch and a radio (JOY CN 2010). In the 1980s and 1990s "the four/five big items" changed to a TV, a washing machine, a refrigerator, an air conditioner and a motorbike (Wang et al. 2006, JOY CN 2010). Since the turn of the century, and particularly since the Beijing Olympics, which opened China to the world, the priorities in household consumption are changing to closely resemble western countries and one of the most desired possessions for a Chinese family is a car (JOY CN 2010). 
The Chinese automobile market has been growing steadily over the last decade and it is expected to expand even more rapidly in the immediate future. In 2009, China surpassed the US as the country with the largest automobile market with annual vehicle sales of 13.6 million, compared to sales of 10.4 million in the US (Guillaume 2010). The primary reason for the expected continued growth of the Chinese automotive market is that current vehicle ownership in China, per capita, is relatively low when compared to both the OECD and other developed countries (Table 2). It is estimated that the number of cars in China will grow from 91 million in 2010 to 400 million in 2030, with the growth mainly driven by private vehicle sales (IEA 2007, NBS 2011b).

At the same time as demand for transportation fuels used for private automobiles and to transport growing volumes of industrial and consumer goods is soaring, China, like many other countries, is facing increasing oil security challenges. Recent reports from the EIA (2011b) have indicated that it will be the non-OECD Asia countries and China in particular that will experience the highest growth in transportation fuel consumption over the next two decades. China is currently the world's second-largest oil consumer and is very likely to overtake the US to become the biggest oil consumer by 2030 (BP 2011a, NBS 2011b). Like the US, China is not self-sufficient in oil (domestic oil produced as a percentage of total oil consumed, at $44 \%$ vs. $46 \%$, respectively, for China and the US) with this ratio predicted to drop to $33 \%$ by 2020 for China (Wang 2010, BP 2011b). Although there are several renewable energy options, such as wind and solar, for China to displace some of its dependency on coal for electricity production, the only viable alternative for transportation is biofuels. As discussed below, there is considerable potential to develop advanced biofuels from China's current forest resource (using mostly residues) and from purpose-grown forest bioenergy crops.

\section{The Potential of Forest-Based Bioenergy and Biofuels in China}

Several countries such as Brazil and the US have reduced their dependency on fossil fuels for transportation by aggressively developing "conventional" or so-called "first-generation" bioethanol-derived from sugar and starch crops. In Europe, and Germany in particular, biodiesel-derived from sunflower, rapeseed and palm oil has been marketed with some success. However, these first-generation or conventional biofuels that are derived from food crops are controversial as they often compete with food production and demands on arable land and water while increasing food prices. This has often been termed the "food versus fuel trade-off" (Bauen et al. 2009).

After an initial investment in corn-based ethanol, resulting in the construction of the world's biggest corn-to-ethanol plant, the Chinese central government decreed no further investment in processes that would convert potential food or feed crops into biofuels (NDRC 2007). China's conventional/first-generation biofuel production is currently limited to four government-authorized bioethanol plants (Henan Tianguan Group Co., Ltd, Jilin Fuel Alcohol Co., Ltd, Anhui BBCA Biochemical Co., Ltd, and $\mathrm{COFCO}^{3}$ Bio-chemical

${ }^{3}$ China National Cereals, Oils and Foodstuffs Corporation
Table 2. Comparison of vehicle ownership

\begin{tabular}{lccccc}
\hline & US & Japan & Canada & World & China \\
\hline Units per 1000 people & $808^{\mathrm{a}}$ & $599^{\mathrm{b}}$ & $581^{\mathrm{b}}$ & $130^{\mathrm{b}}$ & $70^{\mathrm{c}}$ \\
Total units (million) & $250^{\mathrm{a}, \mathrm{d}}$ & $76^{\mathrm{a}, \mathrm{d}}$ & $20^{\mathrm{a}, \mathrm{d}}$ & $884^{\mathrm{a}, \mathrm{d}}$ & $91^{\mathrm{c}}$ \\
\hline
\end{tabular}

Sources: ${ }^{\mathrm{a}}$ Davis et al. 2011, ${ }^{\mathrm{b}}$ Dargay et al. 2007, ${ }^{\mathrm{c}}$ NBS 2011b, ${ }^{\mathrm{d}}$ World Bank 2010b

Energy (Zhaodong) Co., Ltd). The development of first-generation biofuels is unlikely to expand as the amount of available arable land in China is only about $12 \%$ of the total land area and this is projected to further decrease by a further 8 million ha over the next 15 years due to such processes as desertification (C.H. Tian 2008). China is already a net importer of basic items such as sugar, grain and food oil and there is not enough land available for China to become selfsufficient in food production, never mind expanding into biofuel production on its limited arable land (Gale et al. 2002). The production of biofuels from food crops is not an attractive option for a country with a population of 1.3 billion.

Over the last few years the Chinese government has promoted the potential of cellulosic ethanol as a possible biofuel alternative derived from agricultural and forest residues and from sustainably managed forest resources. According to Chinese forest data collected in 2007, there is the potential to produce 12 million to 17 million tonnes of cellulosic ethanol, which would easily exceed the government's 2020 consumption target of 10 million tonnes of second-generation or advanced biofuels (NDRC 2007, Tian 2010, Shi 2011). However, cellulosic ethanol is not yet fully commercialized and the technology has still to resolve the dual challenges of high production and capital costs. As a result, the Chinese government has encouraged research institutes, companies and universities to consolidate their efforts to try to make cellulosic ethanol economically competitive. Leading research institutes at the Chinese Academy of Science (CAS), the Guangzhou Institute of Energy Conversion (GIEC), the National Key Laboratory of Biochemical Engineering (NKLBE) at the Institute of Process Engineering (IPE), and companies such as Henan Tianguan Croup Co., Ltd and COFCO Bio-energy (Zhaodong) Co., Ltd, have all joined forces to try to develop economically and sustainably derived cellulosic biofuels.

To try to catalyze forest-based biodiesel development, the Chinese government has invested in the development of oilseed trees that can grow on marginal land. Once the oils seeds have reach maturity they will be processed to provide the feedstock for commercial biodiesel production. It has been calculated that, at a national level, about 13 million ha of marginal land is suitable for oilseed trees plantations (Shi 2011). However, as these trees require several years to grow and bear fruit, the production of biodiesel from oilseed trees is likely to be, at best, a medium- to long-term, partial solution for the Chinese transportation sector.

The development of first-generation biodiesel or FAME (fatty acid methyl ester) was initially driven by the agriculture and transportation sectors using the raw material (vegetable oil) coming from potential food crops such as rapeseed, canola, sunflowers or from private companies that collected restaurants' waste oil and grease waste (GSI 2008). In order to promote more sustainable use of biodiesel, the Chinese gov- 
ernment released a series of regulations and targets such as the China Renewable Energy Law in 2005, Biodiesel blend stock (BD100) for diesel engine fuels in 2007 and Biodiesel fuel blend (B5) in 2010. Although these policies limited the growth of food- or feed-derived biofuels they were not sufficiently attractive or proactive to result in increased biodiesel production capacity due to the limited supply of waste oil (NPC 2005, China New Energy 2010). Thus, the development of oilseed trees on marginal lands is likely to be one of the few major initiatives that could increase biodiesel production in the Chinese transportation sector.

To try to "kick-start" forest-based bioenergy, the primary focus of the Chinese government's strategy has been to develop and grow combined heat and power generation. This strategy has the dual goal of reducing coal consumption and to encourage some of the forest-rich, remote rural areas to become more energy self-sufficient (NDRC 2007). The Chinese government has followed a two-phase approach with regard to setting targets to replace fossil fuels with forestbased bioenergy. First, by replacing 7 million tonnes of standard coal equivalent (tce) fossil fuel by 2015 (90\% of heating generation and $10 \%$ of biodiesel production), and secondly, by replacing 20 million tonnes of tce fossil fuel (composed of $70 \%$ heating generation; $25 \%$ biodiesel and 5\% bioethanol production) by 2020 (Zhao 2012). Another reason for encouraging the development of combined heat and power generation using forest-based biomass is to further reduce GHG emissions. For example, 22000 ha of bioenergy focused willow plantations (Salix psammophila) have been planted in the desert areas of Inner Mongolia with a goal of producing electricity as part of the Clean Development Mechanism ${ }^{4}$ (CDM) while sequestering nearly 254000 tonnes of $\mathrm{CO}_{2}$ equivalent GHG by 2007 (NDRC 2009). While there are currently no commercial forest biomass-to-biofuels plants operating in China at this time, there is a significant amount of research and development being carried out by university and government groups. In parallel, companies such as COFCO have constructed and are running demonstration plants to evaluate the technical and economic viability on wood-to biofuel processes.

\section{Conclusions}

As the world's largest emerging economy China's energy consumption continues to grow, with coal still predominating as the main energy feedstock, although oil use is rapidly catching up. As the country with the world's largest population, China is already a net grain importer and arable land is scarce. Consequently, China will not expand the production of conventional/ first-generation biofuels derived from edible crops such as sugarcane, corn, or oil crops such as canola and sunflower. As a result the central and regional governments are encouraging the development of second-generation/ advanced biomass-based biofuels as possible solutions to reducing both the rate of China's coal and oil demand as well as the resulting increase in GHG emissions. Although biomass-derived biofuels are not yet commercially available,

\footnotetext{
${ }^{4}$ Under the Kyoto Protocol, developed countries have GHG emissions reductions targets that can be bought from developing countries with certified emission reduction (CER) credits earned through emission-reduction projects.
}

policies have been put in place to encourage the development of bioenergy-focussed forests grown on poor lands to sequester carbon, reduce soil erosion and provide rural employment. The development of bioenergy, and biofuels in particular, combined with the availability of cheap and convenient feedstock for potential bioconversion technologies will help reduce China's dependency on fossil fuels and at least partially contribute to reducing its high level of carbon emissions from fossil fuels.

\section{Acknowledgements}

LL would like to thank Dr. David Cohen and the other members of the organizing committee for giving her the opportunity to present her work at the Future Forestry Leaders Symposium held at UBC, Vancouver, on February 2012. She is also grateful for financial support provided by the NSERC strategic ForValueNet network.

\section{References}

Bauen, A., G. Berndes and M. Junginger. 2009. Bioenergy - a Sustainable and Reliable Energy Source: A review of status and prospects. IEA Bioenergy of IEA, Paris. 108 p. Available at http://www.ieabioenergy.com/LibItem.aspx?id=6479 [Accessed November 4, 2010].

[BP] British Petroleum. 2011a. BP Energy Outlook 2030. London. 80 p. Available at http://www.bp.com/liveassets/bp_internet/globalbp/globalbp_uk_english/reports_and_publications/statistical_ene rgy_review_2011/STAGING/local_assets/pdf/2030_energy_outlook_booklet.pdf [Accessed May 10, 2011].

2011b. Statistical Review of World Energy 2011. London. 49 p. Available at http://www.bp.com/assets/bp_internet/globalbp/ globalbp_uk_english/reports_and_publications/statistical_energy_ review_2011/STAGING/local_assets/pdf/statistical_review_of_ world_energy_full_report_2011.pdf [Accessed July 4, 2011].

China New Energy. 2010. Certified B5 can hardly resolve the growing demand of transportation fuels in China [in Chinese]. Available at http://www.newenergy.org.cn/html/01012/1281037573.html [Accessed October 10, 2011].

Dargay, J., D. Gately and M. Sommer. 2007. Vehicle Ownership and Income Growth, Worldwide: 1960-2030. The Energy Journal 28(4): 143-170.

Davis, S. C., S. W. Diegel and R.G. Boundy. 2011. Transportation energy data book: edition 30. Oak Ridge National Laboratory, Tennessee. 414 p. Available at http://cta.ornl.gov/data/tedb30/Edition30_Full_Doc.pdf [Accessed September 15, 2011].

[DIITHN] Department of Industry and Information Technology of Henan Province. 2009. Replacing Oil with Biofuels is the Best Option [in Chinese]. Available at http://www.iitha.gov.cn/newsshow. asp?id=3852\&typeNumber $=00200004$ [Accessed August 20, 2011].

[EIA] US Energy Information Administration. 2011a. China. Available at http://www.eia.gov/countries/cab.cfm?fips $=\mathrm{CH}$ [Accessed July 4, 2012].

2011b. International Energy Outlook 2011. US Department of Energy, Washington. 338 p. Available at http://www.eia.gov/forecasts/ieo/pdf/0484(2011).pdf [Accessed October 28, 2010].

Gale, F., F. Tuan, B. Lohmar, H. H. Hsu and B. Gilmour. 2002. China's Food and Agriculture: Issues for the 21st Century. Economic Research Service, US Department of Agriculture. Washington. 64 p. Available at http://www.ers.usda.gov/publications/aib775/aib775.pdf [Accessed Feb 10, 2012].

[GSI] Global Subsidies Initiative. 2008. Biofuels - At What Cost ? Government support for ethanol and biodiesel in China. International Institute for Sustainable Development, Geneva. 78 p. Available at http://www.iisd.org/gsi/sites/default/files/china_biofuels_subsidies.pdf [Accessed January 20, 2011]. 
Guillaume, G. 2010. China car sales top US. Reuters, US. Available at http://www.reuters.com/article/2010/01/11/us-autos-idUSTRE60 A1BQ20100111 [Accessed Feb 20, 2012].

[IEA] International Energy Agency. 2007. World Energy Outlook 2007 China and India Insights. Paris. 674 p. Available at http:// www.worldenergyoutlook.org/docs/brainstorming_presentation.pdf [Accessed December 10, 2011].

JOY CN. 2010. Changes of the big four items in six decades [in Chinese]. Available at http://news.joy.cn/China60/consumer/index. shtml [Accessed July 4, 2012].

[NBS] National Bureau of Statistics of China. 2000. Statistics bulletin of national economy and social development 1999 [in Chinese]. Beijing. Available at http://www.stats.gov.cn/tjgb/ndtjgb/qgndtjgb/ t20020331_15394.htm [Accessed September 5, 2011 ].

2011a. China Energy Statistics Yearbook 2010 [in Chinese]. Beijing. Available at http://www.yearbookinfo.net/news.asp?id=685 [Accessed February 15, 2011].

. 2011b. Statistics bulletin of national economy and social development 2010 [in Chinese]. Beijing. Available at http://www. stats.gov.cn/tjgb/ndtjgb/qgndtjgb/t20110228_402705692.htm [Accessed Augest 30, 2011].

[NDRC] National Development and Reform Commission. 2007. Medium and Long-Term Development Plan for Renewable Energy in China [in Chinese]. Beijing. 32 p. Available at http://www. ccchina.gov.cn/WebSite/CCChina/UpFile/2007/20079583745145.pdf [Accessed January 20, 2011].

2009. CDM project of Inner Mongolia Wushenzhao Biomass-fired Project(30MW). Clean Development Mechanism in China [in Chinese]. Beijing. 1 p. Available at http://cdm. ccchina.gov.cn/website/CDM/pdf/Item_new/Item_new1696.pdf [Accessed February 5, 2012].

[NPC] National People's Congress. 2005. China's Renewable Energy Law [in Chinese]. Available at http://www.npc.gov.cn/wxzl/ wxzl/2005-04/25/content_337639.htm [Accessed March 30, 2011].

Shi, Y. C. 2011. China's resources of biomass feedstock [in Chinese]. China Engineer Science 13(2): 16-23.

[SFA] State Forestry Administration. 2011. Forestry bioenergy raw material base inspection and check methods [in Chines]. Beijing. 12 p. Available at http://www.forestry.gov.cn/uploadfile/main/ 2011-5/file/2011-5-23-aaad370c436a4c1cbf20c9349b125319.doc [Accessed September 6, 2011].
Tian, C.H. 2008. The national arable land area reduced to 122 million hectares. Ministry of Land Resources of People's Republic of China [in Chinese]. Beijing. Available at http://www.mlr.gov.cn/ xwdt/jrxw/200804/t20080417_671322.htm [Accessed March 1, 2012].

Tian, Y.S. 2010. Potential feedstocks for the development of 2nd generation biofuels in China [in Chinese]. Energy of China 32(7): 17-20.

Vaughn, J. 2011. Chapter 6 The Politics of Energy. In C. Merrill (ed.). Environmental politics: domestic and global dimensions, sixth edition. Pp. 162-188, Wadsworth Press, Boston.

Wang, H.B. 2010. Characteristics and Trends of China's Oil Demand. Paper presented at the World Energy Congress Montreal 2010, Montreal. 15 p. Available at http://www.worldenergy.org/documents/congresspapers/83.pdf [Accessed Oct 10, 2011].

Wang, L. 2008. Attribution Factors and Problems of Energy Consumption since the Reform and Open-up in China. Teaching and Research 2008(10): 29-36.

Wang, M., H. Huo, L. Johnson and D. He. 2006. Projection of Chinese Motor Vehicle Growth, Oil Demand, and $\mathrm{CO}_{2}$ Emissions through 2050 [in Chinese]. Argonne National Laboratory, IL. 70 p. Available at http://www.transportation.anl.gov/pdfs/TA/398.pdf [Accessed March 10, 2011].

World Bank. 2010a. Energy use (kg of oil equivalent per capita) [online]. Available at http://data.worldbank.org/indicator/EG.USE. PCAP.KG.OE/countries/1W-CN-US-CA?display=default [Accessed September 4, 2011].

- 2010b. Population total [online]. Available at http:// data.worldbank.org/indicator/SP.POP.TOTL [Accessed May 14, 2012].

. 2011. GDP (current US\$) [online]. Available at http:// data.worldbank.org/indicator/NY.GDP.MKTP.CD [Accessed March $5,2012]$.

Zhao, Q. 2012. The goals of national forest-based bioenergy determined [in Chinese]. State Forestry Administration, Beijing. Available at http://www.forestry.gov.cn/portal/main/s/72/content-520064 .html [Accessed February 4, 2012]. 